\title{
Understanding the Costs and Benefits of State-Level Immigration Policies
}

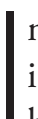
$\mathrm{n}$ the past 15 years, faced with a lack of comprehensive immigration reform at the federal level, almost all states have moved to enact their own policies regarding unauthorized immigrants. These policies predominantly center on law enforcement, employment verification, higher education, driver's licenses, and public benefits.

The growing role of states in these areas of immigrationrelated policy raises questions about the consequences of state-level action for various stakeholders in the public and private sectors. To inform these policy discussions, RAND researchers

- documented the state-level policy landscape

- developed a cost-benefit framework for classifying consequences of specific state-level policies, identifying potential domains of impact and how different stakeholders would be affected

- reviewed research literature to compile empirical evidence, where it exists, regarding likely magnitudes of the impacts of specific state-level immigration-related policies

- used the cost-benefit framework, together with the assembled empirical evidence, to assess the rigor and relevance of existing studies of the fiscal and economic impacts of specific policy actions.

\section{Landscape of State Immigration Policies}

Motivated by concerns about unauthorized immigrants' effects on state budgets and the economy more broadly, some states have pursued policies that are restrictive relative to the status quo to reduce the number of unauthorized immigrant residents or to discourage newcomers (see Table 1). In six states (Alabama, Arizona, Georgia, Indiana, South Carolina, and Utah), these policies have been packaged in omnibus legislation that place multiple restrictions on unauthorized immigrants. Other states have enacted specific laws or policiessuch as involving local law enforcement in upholding federal immigration laws or requiring some or all employers to use a federally operated voluntary system, E-Verify-to determine whether a prospective employee is a U.S. citizen or otherwise legally authorized to work in the United States.

Other states have adopted policies that are unrestrictive toward unauthorized immigrants (see Table 2). For example,

\section{Key findings:}

- As of June 2015, all but 11 states had enacted one or more of the policies examined. Sixteen states had primarily restrictive policies, 14 had mostly unrestrictive polices, and nine had a mix of policies.

- The most prevalent restrictive policy, adopted in 22 states, was the mandatory use of E-Verify for all or some subset of public and private employers. The most common unrestrictive policy, in effect in 20 states, was access to in-state tuition regardless of immigration status.

- The six states with the largest populations of unauthorized immigrants had either unrestrictive policies (California, Illinois, New Jersey, and New York) or a combination of restrictive and unrestrictive policies (Florida and Texas).

- State-level policies might produce impacts in multiple domains and could have spillover effects on nontargeted populations. A cost-benefit analysis can assess the full range of potential impacts, both in the aggregate and for specific stakeholders.

- Some expected effects of state-level policies can be clearly designated as positive, negative, or neutral for specific stakeholders. Other outcomes are less certain in terms of expected net benefits.

- Few formal cost-benefit analyses of state-level policies have been conducted. Such analyses could support relevant decisionmaking.

as of June 2015, 20 states allowed unauthorized immigrants access to in-state tuition or financial aid at public colleges and universities when they otherwise meet the residency rules and other eligibility requirements. Other such unrestrictive policies include removing immigration status as an eligibility criterion for state-issued driver's licenses and for publicly subsidized prenatal care for pregnant women and health insurance for children. 
Table 1. Common State-Level Policies That Are Restrictive Toward Unauthorized Immigrants

\begin{tabular}{|c|c|c|c|}
\hline Policy & Status Quo & Policy Alternative & $\begin{array}{c}\text { Number of States with Policy } \\
\text { as of June } 2015\end{array}$ \\
\hline $\begin{array}{l}\text { Omnibus immigration } \\
\text { legislation }\end{array}$ & $\begin{array}{l}\text { State has no express policy regarding } \\
\text { immigration-related law enforcement, use of } \\
\text { E-Verify or other status verification systems, } \\
\text { in-state tuition, driver's licenses, or access to } \\
\text { public benefits }\end{array}$ & $\begin{array}{l}\text { State places multiple restrictions on } \\
\text { unauthorized immigration in such domains } \\
\text { as law enforcement, employment, higher } \\
\text { education, driver's licenses, and access to } \\
\text { public benefits }\end{array}$ & 6 \\
\hline $\begin{array}{l}\text { Immigration-related } \\
\text { law enforcement }\end{array}$ & $\begin{array}{l}\text { State has no express policy to enforce federal } \\
\text { immigration policy }\end{array}$ & $\begin{array}{l}\text { State prohibits law enforcement from restricting } \\
\text { enforcement of federal immigration laws }\end{array}$ & $8^{a}$ \\
\hline $\begin{array}{l}\text { E-Verify or other status } \\
\text { verification systems }\end{array}$ & $\begin{array}{l}\text { Use of E-Verify by public and private employers } \\
\text { in the state is voluntary }\end{array}$ & $\begin{array}{l}\text { Use of E-Verify is mandatory for all or some } \\
\text { subset of public and private employers }\end{array}$ & 22 \\
\hline
\end{tabular}

a Does not include states with agreements under Section 287(g) of the Immigration and Nationality Act, codified at 8 USC § 1357.

Table 2. Common State-Level Policies That Are Unrestrictive Toward Unauthorized Immigrants

\begin{tabular}{|c|c|c|c|}
\hline Policy & Status Quo & Policy Alternative & $\begin{array}{c}\text { Number of States with Policy } \\
\text { as of June } 2015\end{array}$ \\
\hline $\begin{array}{l}\text { In-state tuition and } \\
\text { other financial aid }\end{array}$ & $\begin{array}{l}\text { State does not allow unauthorized immigrants } \\
\text { to receive in-state tuition or other financial aid } \\
\text { at public colleges and universities for which } \\
\text { they otherwise qualify }\end{array}$ & $\begin{array}{l}\text { State allows unauthorized immigrants to receive } \\
\text { in-state tuition (and financial aid) at public } \\
\text { colleges and universities provided they meet } \\
\text { graduation, residency, and other requirements }\end{array}$ & $20^{a}$ \\
\hline $\begin{array}{l}\text { Driver's license } \\
\text { eligibility }\end{array}$ & $\begin{array}{l}\text { Unauthorized immigrants are not eligible for } \\
\text { state-issued driver's license }\end{array}$ & $\begin{array}{l}\text { Unauthorized immigrants are eligible for state- } \\
\text { issued driver's license }\end{array}$ & 12 \\
\hline $\begin{array}{l}\text { Health care access for } \\
\text { pregnant women and } \\
\text { children }\end{array}$ & $\begin{array}{l}\text { Unauthorized immigrants are not eligible for } \\
\text { publicly subsidized health insurance or medical } \\
\text { care }\end{array}$ & $\begin{array}{l}\text { Unauthorized pregnant women are eligible } \\
\text { for publicly subsidized prenatal care and/or } \\
\text { unauthorized children are eligible for publicly } \\
\text { subsidized health insurance }\end{array}$ & 18 \\
\hline
\end{tabular}

a This number reflects only states with unrestrictive in-state tuition and financial aid policies, and does not include seven states with policies that explicitly deny unauthorized immigrants eligibility for in-state tuition.

As of June 2015, all but 11 states had adopted one or more of the policies listed in Tables 1 and 2 (see map).

Sixteen states had at least one restrictive policy, 14 had at least one unrestrictive policy, and nine had adopted a mixture of both restrictive and unrestrictive policies. Of the six states with the largest number of unauthorized immigrants, four-California, Illinois, New Jersey, and New Yorkhad unrestrictive policies, while the other two-Florida and Texas - had a mixture of policies, namely mandating the use of E-Verify but allowing unauthorized immigrants access to in-state tuition.

\section{A Tool to Better Understand Costs and Benefits of Immigration Policies}

To contribute to a better understanding of the potential impacts of state-level immigration policies, RAND researchers drew first on theoretical considerations and empirical evidence to develop a cost-benefit framework for each of the policies in Tables 1 and 2. Each framework identifies the set of effects a policy might have and how those effects create costs or benefits for the following stakeholders: unauthorized immigrants, authorized immigrants (including naturalized U.S. citizens), the native-born, employers, and state and local governments. Aggregating across stakeholders provides the societal perspective of the costs and benefits of any given policy.

As part of their analysis, the authors reviewed empirical studies examining the causal impact of each policy as implemented. Most of the available research exploits the variation across states and through time in the policy environment to estimate the impact of one or more policies (or policy variants) on the level and share of key population subgroups (e.g., unauthorized immigrants), labor market outcomes (e.g., employment and wages), and other relevant outcomes (e.g., educational attainment in the case of in-state tuition policy).

The cost-benefit frameworks developed in the study can be used to illuminate the array of impacts that any given policy may have and which stakeholders are expected to experience 
Summary Status of State Immigration Policy as of June 2015

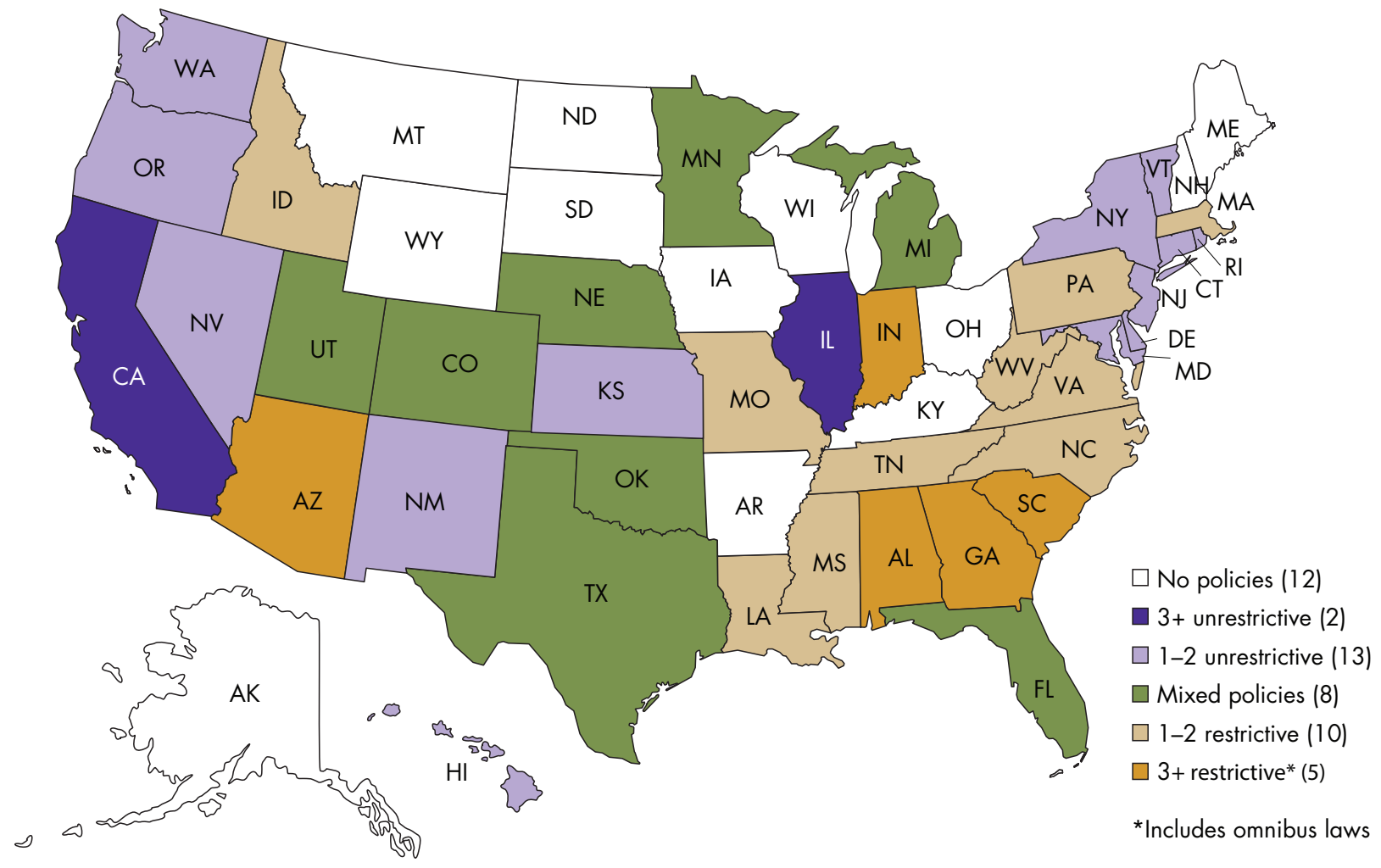

costs or benefits. Each framework can also be a guide to the development of future cost-benefit analyses (CBAs) of any given policy or in the assessment of the quality of prior CBAs.

\section{Insights from the Frameworks and Literature}

These frameworks and accompanying literature review produced a number of key findings.

\section{State-level policies may produce effects in multiple domains,} including spillover effects for diverse stakeholders. Whether omnibus legislation or a more targeted policy change, state-level immigration policy impacts may accrue in multiple policy domains. For example, impacts may be found not only in the size of the unauthorized population in the state, but also in the level and distribution of state economic activity; levels of employment and wages, sectoral makeup of employment opportunities, and relative wages across worker subgroups based on skill; educational enrollment and attainment; law enforcement and the criminal justice system; the social welfare system; population health and utilization of health care; and state and local government taxes and expenditures. Although unauthorized immigration is often the target of state-level immigration policy, theory would suggest (and empirical evidence confirms) that there can be spillover consequences for authorized immigrants and the native-born population. This is especially true for policies that affect the labor market, and also arises when policies have consequences for mixed-status families, in which one or both parents are unauthorized immigrants but some or all of their children are native-born U.S. citizens. CBAs can help policymakers assess the full range of potential impactsboth intended and unintended-and determine policy costs and benefits in aggregate and for specific stakeholders in the public and private sectors.

\section{Some expected effects have a clear direction of impact;} others are more uncertain. In assessing the expected effects of policies focused on unauthorized immigration, some can be clearly designated as positive, negative, or neutral, in relation to the status quo. In the case of restrictive policies, the first-order effects for the unauthorized immigrant population are typically unfavorable. For example, in states that mandate the use of E-Verify, unauthorized immigrants would likely face decreased employment and loss of earnings. Conversely, policies that are unrestrictive toward unauthorized immigrants, such as making in-state tuition available regardless of immigration status, are expected to clearly benefit such immigrants in terms of both lower outof-pocket education costs and higher lifetime earnings based on higher educational attainment. 
The expected net impact of other outcomes, such as second-order effects on labor supply or labor demand, are less certain. With the E-Verify example, some unauthorized immigrants may experience net gains if wages increase for lower-skilled workers (because of reduced supply from unauthorized immigrants avoiding the state) and if they are able to remain employed through self-employment or if they work in a sector that is not covered by the E-Verify requirement. Given these uncertainties, empirical research that assesses actual outcomes for unauthorized immigrants and other population groups in states adopting immigration policies relative to those that do not could strengthen state-level decisionmaking.

\section{Few formal CBAs of state-level immigration policies have been conducted}

Although a formal CBA would more thoroughly identify the expected net effects of a given policy for any particular stakeholder group or for society as a whole, the authors identified few formal CBAs of state-level policies in their review of the literature. Many studies calculate the net fiscal or economic impact of immigration in total or unauthorized immigration in particular, but do not provide analyses of specific statelevel policies and their impacts. Other studies focus on the costs or benefits of specific immigration policies or bundles of policies to support or oppose a policy change and therefore do not provide a comprehensive, balanced assessment that considers net impacts on all stakeholders. In many cases, such studies do not incorporate empirical evidence regarding policy impacts and instead rely on ad hoc assumptions about such effects. Two CBAs reviewed by the authors demonstrate the insights that can be gained from rigorous CBAs, including estimates of overall economic and fiscal impacts, as well as distributional consequences. For example, a CBA of the Maryland Dream Act shows that granting unauthorized immigrants access to in-state tuition would pass a cost-benefit test in aggregate and for the public sector under a range of assumptions. The RAND framework also helps identify any unmeasured impacts in CBAs and the implications for the bottom-line conclusions of the CBA.

\section{Predominance of certain state policies may reflect underlying cost-benefit calculations}

Notwithstanding the limited number of formal CBAs focused on state-level immigration policies, the evidence does appear to indicate that stakeholders have been performing such cost-benefit calculations implicitly in making policy decisions at the state and local levels. For example, each of the top six states where unauthorized immigrants reside has extended in-state tuition to unauthorized immigrants, and California and Texas make state financial aid available as well. Indeed, in-state tuition eligibility for unauthorized immigrants is the most prevalent of the unrestrictive policies the study examined, enacted in 20 states, suggesting that policymakers have recognized a likely positive economic return and savings to government from investing in the education of all immigrants, regardless of status.

\section{Policy Implications}

State-level action on immigration policies in the face of inaction by the federal government continues to be a contentious issue, reflecting the fact that such policies have distributional consequences with winners and losers. In such an environment, the application of a cost-benefit framework to assess state-level immigration policies can offer a more objective, balanced picture of the expected positive and negative effects of such policies, including the dollar values associated with those outcomes, whether society as a whole benefits from the policy change, and which stakeholder groups are likely to experience net gains versus net losses.

The recent pace of state-level policymaking in this area suggests this will be a critical and ongoing policy challenge. RAND's framework offers governors, legislators, and other state and local decisionmakers a useful tool to evaluate both existing policies and those they may push for in the future.

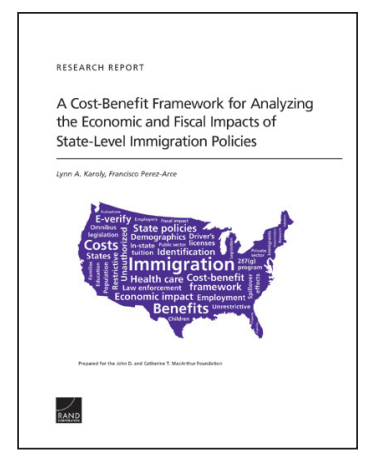

This brief describes work done in RAND Labor and Population documented in A Cost-Benefit Framework for Analyzing the Economic and Fiscal Impacts of State-Level Immigration Policies, by Lynn A. Karoly and Francisco Perez-Arce, RR-1397-MCF, 2016 (available at www.rand.org/t/RR1397). To view this brief online, visit www.rand.org/t/RB9923. The RAND Corporation is a research organization that develops solutions to public policy challenges to help make communities throughout the world safer and more secure, healthier and more prosperous. RAND is nonprofit, nonpartisan, and committed to the public interest. RAND's publications do not necessarily reflect the opinions of its research clients and sponsors. RAND ${ }^{\circledR}$ is a registered trademark. @ RAND 2016

Limited Print and Electronic Distribution Rights: This document and trademark(s) contained herein are protected by law. This representation of RAND intellectual property is provided for noncommercial use only. Unauthorized posting of this publication online is prohibited. Permission is given to duplicate this document for personal use only, as long as it is unaltered and complete. Permission is required from RAND to reproduce, or reuse in another form, any of our research documents for commercial use. For information on reprint and linking permissions, please visit www.rand.org/ pubs/permissions. 